\title{
The Empirical Analysis of the Determinants of Bank-non-Intermediation Income and Gold and Oil Co-movement Analysis
}

\author{
Adama Dembele \\ School of Social Sciences, Istanbul Sabahattin Zaim University
}

\begin{abstract}
This paper consists an introduction and two main parts, the introduction gives abroad idea about the determinants of Bank-non Intermediation Income and the Co-movement happening between the Gold of London Gold Bullion and as well as the Brent, then the first part of the study aims to analysis the determinants of Banknon-Intermediation Income based on evidence and data from the OIC(Organization of Islamic Cooperation ) member Muslim countries. The study uses STATA as a tool to analysis the data from the OIC countries.The objective of the second part is to analysis the co-movement happening between the GOLD of London Gold Bullion in USD and the BRENT (Brent Crude Oil Price) in USD between the period of January 1986 and April 2018. The analysis is based on daily data frequency. The technique of analysis: Wavelet coherence relationship. This study ends with a concluding section which highlights the main findings of the study and suggestions.

Keywords: Determinants, Bank-non-Intermediation Income, OIC countries, Gold of London Gold Bullion, Brent.

DOI: $10.7176 / \mathrm{JESD} / 10-2-01$

\section{Introduction}

The global financial crisis which happened since the year of 2008 has shown the complication of the financial system globally and more practically in the OIC ( Organization of Islamic Cooperation) member Muslim countries, and this raised various concerns on the banking system in these countries(Malim \& Masron, 2018). This concentration on the financial system probably calls for a need of bank margins as an arbitrage of financial intermediation costs. Thus, high margins reproduce high financial intermediation costs and inadequacies (LópezEspinosa, Moreno, \& Pérez de Gracia, 2011). In this regard various financial policies were implemented by governments in the OIC member countries and elsewhere in the world to enhance banking intermediation activities(Malatesta, Fabrizio, n.d.). Being under some high levels of competition, also the increase of the demands facing the banks from both the individual and big corporation customers for products which are sometimes more and more complex and different kind services, the focus of most of the banks was turned in fee making interests(DAMANKAH, TSEDE, \& AMANKWAA, 2014). Furthermore, this study analyses the comovement happening between the Gold of London Gold Bullion in USD and the Brent between the period of January 1986 and April 2018. The London Bullion is a well-known market located in the center of London having a global membership and client base including central banks holders of gold, private sector investors, mining companies and others(LBMA, 2016). It should be noted that due to the recent complexity of the financial markets, at both national and international levels, the investors keep looking for alternatives in their decision making. To overcome this complexity EryiĞit (2017), argues that most investors especial non-professionals invest in Gold, because they look at the Gold as a simple and safe haven for many of the investors. Actually, there are three main motives which drive the demand for the Gold, these motives are the jewellery, industrial dentistry and investment(Baur \& McDermott, 2010). Yet the Crude Oil (Brent) is another investment sector which has attracted the attention of many investors in the "London Bullion". This sector is more different from the Gold investment sector which is safe haven and more liked by the investors("Crude Oil Prices: Brent Europe," 2018).
\end{abstract}




\section{Determinants of Bank Non-Intermediation Income: Evidence from OIC Countries} Data

Table 1: Description of variables

\begin{tabular}{llll}
\hline Variable B_NII Description & & Source \\
\cline { 1 - 1 } & Non-intermediation Income & \\
B_CAP & Capitalization & \\
B_ASQ & Asset Quality & Bank scope \\
B_EFF & Efficiency & \\
B_LIQ & Liquidity & \\
B_SIZ & Bank Size & \\
M_CONL & Lerner index & \\
F_PCRB & Private Credit by Banks & \\
M_RINT & Real Interest Rate & \\
M_ECGR & Economic Growth & \\
M_INFD & Inflation (GDP Deflator) & \\
M_TRDO & Trade Openness & \\
Q_FGOV & Government Spending & \\
M_FINO & Financial Openness & \\
\hline
\end{tabular}

Empirical Results

Table 2: Descriptive statistics

\begin{tabular}{llllllll}
\hline & Obs & Min & Max & Mean & SD & Skew & Kurt \\
\hline Non-intermed. Income & 5459 & -0.0078 & 0.4051 & 0.0215 & 0.0278 & 4.9348 & 41.3018 \\
Capitalization & 5515 & 1.5500 & 88.5900 & 16.5542 & 15.5611 & 2.9389 & 12.2669 \\
Asset Quality & 3736 & 0.0000 & 50.2500 & 8.5583 & 10.8420 & 2.3400 & 8.4212 \\
Efficiency & 5397 & 12.7500 & 217.5400 & 59.0733 & 32.2749 & 2.4540 & 11.7212 \\
Liquidity & 3948 & 1.0300 & 215.1900 & 34.4271 & 27.5634 & 2.9602 & 16.8425 \\
Bank Size & 5506 & 16.8521 & 33.1882 & 25.7708 & 3.9525 & 0.2228 & 2.3120 \\
Lerner index & 7750 & -0.0136 & 0.5777 & 0.3111 & 0.1393 & -0.0716 & 2.4999 \\
Private Credit by Banks & 8460 & 6.5400 & 127.2300 & 44.1606 & 29.9830 & 0.9088 & 3.0377 \\
Real Interest Rate & 6432 & -10.7300 & 45.8100 & 4.8657 & 8.3765 & 1.1034 & 6.4523 \\
Economic Growth & 8573 & -0.0814 & 0.1327 & 0.0503 & 0.0327 & -0.5175 & 5.2958 \\
Inflation (GDP Deflator) & 9181 & -2.9200 & 37.7000 & 9.0097 & 8.6024 & 1.2088 & 4.6633 \\
Trade Openness & 9066 & 28.1300 & 220.4100 & 86.2777 & 42.0651 & 1.1192 & 3.8349 \\
Financial Openness & 8458 & 0.0000 & 100.0000 & 52.7244 & 33.4298 & 0.1370 & 1.5779 \\
Government Spending & 9058 & 10.2000 & 94.9000 & 74.7052 & 12.5268 & -1.1204 & 5.3920 \\
\hline
\end{tabular}

Private Credit by Banks is a proxy of Financial Development of a country. Lerner Index is a proxy for bank concentration. 
Table 3: Correlation matrix

\begin{tabular}{|c|c|c|c|c|c|c|c|c|c|c|c|c|c|}
\hline & 1 & 2 & 3 & 4 & 5 & 6 & 7 & 8 & 9 & 10 & 11 & 12 & 13 \\
\hline 1. B_NII & 1.00 & & & & & & & & & & & & \\
\hline 2. B_CAP & $0.34^{*}$ & 1.00 & & & & & & & & & & & \\
\hline 3.B_ASQ & $0.17^{*}$ & $0.11^{*}$ & 1.00 & & & & & & & & & & \\
\hline 4.B_EFF & 0.01 & $0.11^{*}$ & $0.17^{*}$ & 1.00 & & & & & & & & & \\
\hline 5.B_LIQ & $0.14^{*}$ & $0.46^{*}$ & $0.14^{*}$ & $0.10^{*}$ & 1.00 & & & & & & & & \\
\hline 6.B_SIZ & $-0.06^{*}$ & $-0.29^{*}$ & $-0.08^{*}$ & $-0.03^{*}$ & $-0.16^{*}$ & 1.00 & & & & & & & \\
\hline 7.M_CONL & $0.08^{*}$ & $0.19^{*}$ & $-0.17^{*}$ & $-0.18^{*}$ & $-0.10^{*}$ & $-0.19^{*}$ & 1.00 & & & & & & \\
\hline 8.F_PCRB & $-0.13^{*}$ & -0.02 & 0.02 & $-0.09^{*}$ & 0.01 & $-0.20^{*}$ & -0.01 & 1.00 & & & & & \\
\hline 9.M_RINT & -0.01 & -0.03 & $0.09^{*}$ & $0.09^{*}$ & $0.07^{*}$ & 0.02 & $-0.15^{*}$ & $-0.11^{*}$ & 1.00 & & & & \\
\hline 10.M_ECGR & $0.08^{*}$ & $0.05^{*}$ & $-0.10^{*}$ & $-0.05^{*}$ & $0.06^{*}$ & -0.01 & 0.01 & $-0.17^{*}$ & $-0.07^{*}$ & 1.00 & & & \\
\hline 11.M_INFD & $0.11^{*}$ & 0.02 & -0.01 & 0.00 & 0.01 & $0.18^{*}$ & $-0.04^{*}$ & $-0.33^{*}$ & $-0.72^{*}$ & $0.14^{*}$ & 1.00 & & \\
\hline 12.M_TRDO & -0.00 & $0.14^{*}$ & -0.03 & $-0.15^{*}$ & $0.04^{*}$ & $-0.52^{*}$ & $0.21^{*}$ & $0.68^{*}$ & $-0.14^{*}$ & 0.00 & $-0.22^{*}$ & 1.00 & \\
\hline 13.M_FINO & $-0.08^{*}$ & $0.09^{*}$ & $-0.04^{*}$ & $-0.15^{*}$ & $0.07^{*}$ & $-0.24^{*}$ & $0.19^{*}$ & $0.07^{*}$ & 0.01 & $-0.06^{*}$ & $-0.12^{*}$ & $0.19^{*}$ & 1.00 \\
\hline 14.Q_FGOV & 0.00 & -0.02 & $-0.13^{*}$ & $0.10^{*}$ & $-0.07^{*}$ & $0.25^{*}$ & $-0.13^{*}$ & $-0.18^{*}$ & $-0.07^{*}$ & $0.11^{*}$ & $0.06^{*}$ & $-0.08^{*}$ & $-{ }^{-} .14^{*}$ \\
\hline
\end{tabular}

$p<0.05$

To begin with, the correlation test (see Table 3) was done to see which variables were correlated to Nonintermediation income, and to know how significant those variables were. It was found that all the variables were significant except four variables. The bank efficiency was positive correlated to the Non-intermediation income, but insignificant. This simply indicates that, the higher the non-intermediation income is, the higher the bank efficiency is in cost.

On the other hand, the real interest rate was negative correlated to non-intermediation income, and insignificant at the same time. Again, the correlation between the trade openness and the non-intermediation income was negative and trade openness was also insignificant.

Lastly, the government spending was also positively correlated to non-intermediation income but insignificant which means, the government spending increases if the non-intermediation income is high.

Likewise, the test for differences in means with unequal variables (Table 4) was done to identify the efficiency of the variables. Using the t-test, the Non-intermediation Income was negative meaning, the Islamic banks are better than the conventional banks, as well as in term of bank capitalization, Islamic banks were better performing compared to the commercial banks. However, there was a high inefficiency for the Islamic banks besides the conventional banks. At the same time, the asset quality was positive and significant, which determines that the default with the conventional banks is relatively bigger in comparison with the Islamic banks. While there was no much difference between the two institutions in the bank liquidity. The bank size was positive and significant, showing that the convention banks are bigger than the Islamic banks.

Table 4: T-tests for difference in means

\begin{tabular}{|c|c|}
\hline Non-intermediation Income & $-0.006^{* *}[0.001]$ \\
\hline Capitalization & $\begin{array}{l}10.571^{* *} \\
0.796]\end{array}$ \\
\hline Asset Quality & $\begin{array}{l}1.371^{* *} \\
{[0.511]}\end{array}$ \\
\hline Efficiency & $\begin{array}{l}-5.939^{* *} \\
-1.334]\end{array}$ \\
\hline Liquidity & $\begin{array}{l}-1.898 \\
{[1.961]}\end{array}$ \\
\hline $\begin{array}{l}\text { Bank Size } \\
\text { on } 1.487^{* *} \quad[0.158]\end{array}$ & $\begin{array}{l}1.487^{* *} \\
{[0.158]}\end{array}$ \\
\hline Observations & 5515 \\
\hline
\end{tabular}

Independent group t-tests for differences in means with unequal variances Standard errors in brackets

${ }^{*} p<0.1,{ }^{* *} p<0.05$ 
Table 4: Estimation outputs

\begin{tabular}{|c|c|c|c|c|}
\hline & POLS & FIX & RAN & FIXRobust \\
\hline \multirow[t]{2}{*}{ L.Capitalization } & $0.00034^{* * *}$ & -0.00005 & $0.00022^{* * *}$ & -0.00005 \\
\hline & {$[0.00006]$} & {$[0.00009]$} & {$[0.00006]$} & {$[0.00014]$} \\
\hline \multirow[t]{2}{*}{ L.Asset Quality } & $0.00016^{* * *}$ & $0.00009^{*}$ & $0.00009^{*}$ & 0.00009 \\
\hline & {$[0.00004]$} & {$[0.00004]$} & {$[0.00004]$} & {$[0.00010]$} \\
\hline \multirow[t]{2}{*}{ L.Efficiency } & $0.00004^{* *}$ & $-0.00003^{*}$ & 0.00000 & -0.00003 \\
\hline & {$[0.00001]$} & {$[0.00001]$} & {$[0.00001]$} & {$[0.00003]$} \\
\hline \multirow[t]{2}{*}{ L.Liquidity } & 0.00000 & $0.00005^{*}$ & $0.00004^{*}$ & 0.00005 \\
\hline & {$[0.00002]$} & {$[0.00002]$} & {$[0.00002]$} & {$[0.00004]$} \\
\hline \multirow[t]{2}{*}{ L.Bank Size } & -0.00027 & $-0.00488^{* * *}$ & $-0.00054^{*}$ & $-0.00488^{* *}$ \\
\hline & {$[0.00014]$} & {$[0.00086]$} & {$[0.00025]$} & {$[0.00167]$} \\
\hline \multirow[t]{2}{*}{ Lerner index } & 0.00152 & $0.01435^{*}$ & 0.00765 & 0.01435 \\
\hline & {$[0.00468]$} & {$[0.00638]$} & {$[0.00512]$} & {$[0.00955]$} \\
\hline \multirow[t]{2}{*}{ Private Credit by Banks } & $-0.00022^{* * *}$ & 0.00005 & $-0.00020^{* * *}$ & 0.00005 \\
\hline & {$[0.00003]$} & {$[0.00005]$} & {$[0.00003]$} & {$[0.00005]$} \\
\hline \multirow[t]{2}{*}{ Real Interest Rate } & $0.00041^{\text {**** }}$ & $-0.00019^{* *}$ & -0.00002 & $-0.00019^{*}$ \\
\hline & {$[0.00009]$} & {$[0.00007]$} & {$[0.00007]$} & {$[0.00008]$} \\
\hline \multirow[t]{2}{*}{ Economic Growth } & $0.08838^{* * *}$ & $0.03403^{* *}$ & $0.04969^{* * *}$ & $0.03403^{*}$ \\
\hline & {$[0.01446]$} & {$[0.01142]$} & {$[0.01145]$} & {$[0.01672]$} \\
\hline \multirow[t]{2}{*}{ Trade Openness } & $0.00011^{* * *}$ & $0.00009^{* * *}$ & $0.00007^{* *}$ & $0.00009^{* *}$ \\
\hline & {$[0.00002]$} & {$[0.00003]$} & {$[0.00002]$} & {$[0.00003]$} \\
\hline \multirow[t]{2}{*}{ Financial Openness } & $-0.00005^{* *}$ & -0.00005 & $-0.00006^{*}$ & -0.00005 \\
\hline & {$[0.00002]$} & {$[0.00003]$} & {$[0.00002]$} & {$[0.00003]$} \\
\hline \multirow[t]{2}{*}{ Inflation } & $0.00028^{*}$ & $-0.00032^{* * *}$ & -0.00015 & $-0.00032^{* *}$ \\
\hline & {$[0.00012]$} & {$[0.00009]$} & [0.00009] & {$[0.00012]$} \\
\hline \multirow[t]{2}{*}{ Constant } & 0.00697 & $0.13305^{* * *}$ & $0.02657^{* *}$ & $0.13305^{* \bar{*}}$ \\
\hline & {$[0.00601]$} & {$[0.02301]$} & {$[0.00840]$} & {$[0.04427]$} \\
\hline Observations & 1268 & 1268 & 1268 & 1268 \\
\hline Time Effects & Yes & Yes & Yes & Yes \\
\hline
\end{tabular}

Standard errors in brackets

${ }^{*} p<0.05,{ }^{* *} p<0.01,{ }^{* * *} p<0.001$

When the regression (see Table 4) was done by using the time effects, then the models were compared to know which one was reliable to use. The first comparison between Pooled OLS and Random Effects, the P-value was less than 5\%, where the suggestion was to use Random Effects if the p-value is less than 5\%. The second comparison was between Random Effects and the Fixed Effects, still it is said if the p-values is less than 5\% to use Fixed Effects. Lastly, the Hausman test was done to judge between the two models where it is said to use Random Effects if p-value is higher than 5\% and Fixed Effects if p-value is less than 5\%. The Fixed Effects was found appropriate model for the analysis.

Statically, the model showed that all the bank Capitalization, Asset Quality, Bank Efficiency, Liquidity, Lerner index, Private Credit by Banks, Financial Openness are insignificant. But the Bank size had negative impact on the Non-intermediation Income, similarly the Real Interest Rate and the Inflation had negative impact on the Non-intermediation Income. On the other side, only the Economic Growth and the Trade Openness were found to have positive impact on the Non-intermediation Income. 


\section{Gold and Oil Co-movement Analysis}

Data

Variables: GOLD: London Gold Bullion in USD; BRENT: Brent Crude Oil Price in USD

Data range: January 1986 - April 2018

Number of observations: 8417

Frequency of data: Daily

Table 1: Descriptive statistics

\begin{tabular}{lcc}
\hline Statistics & BRENT & GOLD \\
\hline Mean & $0.005 \%$ & $0.007 \%$ \\
Min & $-15.826 \%$ & $-4.413 \%$ \\
Max & $20.470 \%$ & $3.206 \%$ \\
S.D. & $1.023 \%$ & $0.422 \%$ \\
Kurtosis & 55.44 & 7.58 \\
Skewness & 0.48 & -0.35 \\
Correlation & & 0.12 \\
\hline
\end{tabular}

Figure 1: Gold and oil price dynamics

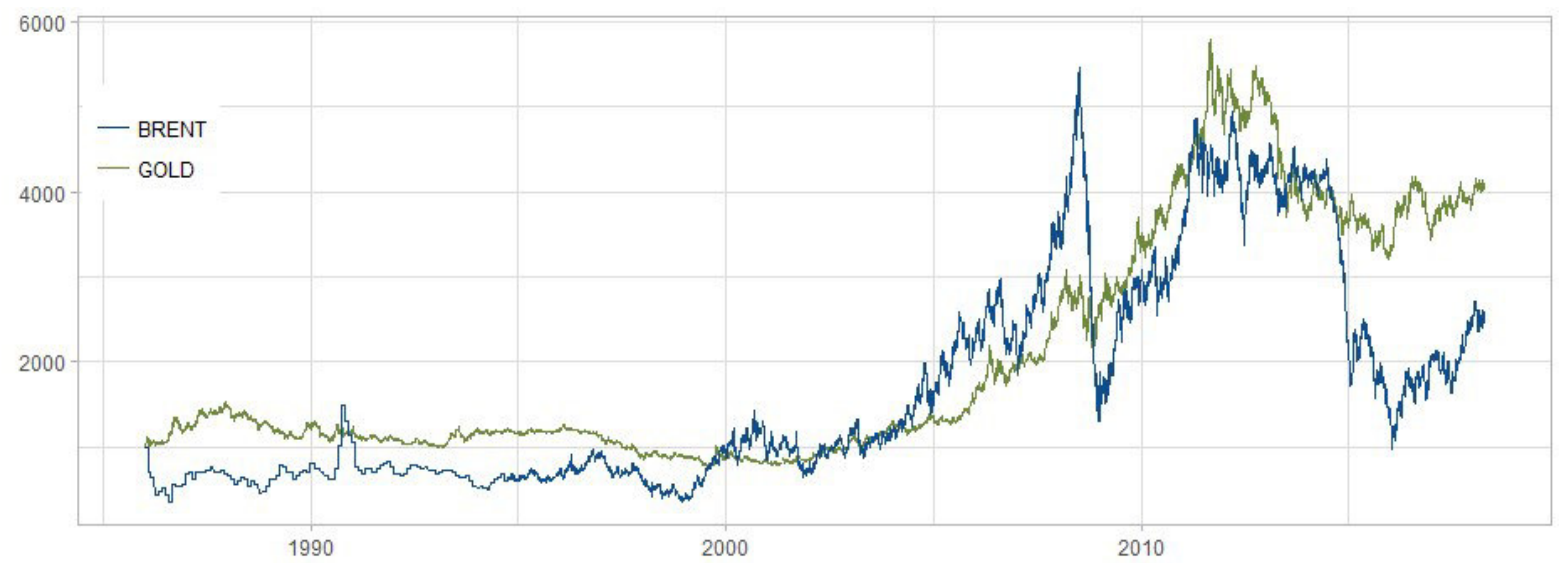

The line graphs show that around 1991, the price of Brent for the first time went over and above the price of Gold to reach almost $\$ 1500$, but there was a sudden drop in price from around $\$ 1500$ to nearly $\$ 700$. And thereafter both Gold and Brent prices moved in the same direction until 1998, when again the price of Brent started experiencing rises and went above the price of Gold to record a range of $\$ 1300$. Starting from the year of 2002 , both Gold and Brent prices started fluctuating in the same range of relatively above $\$ 1000$. Then by the year of 2005, both two commodities prices were moving upwards, however the prices of Brent went up to record a number slightly more than $\$ 2000$, and remained steadied to $\$ 3000$ in the following year, whereas, the prices of Gold also moved slightly around $\$ 1200$ reaching a bit above $\$ 2000$ in the year of 2006 . While almost in the same year there was a high increase in price of Brent to hit a pick almost at $\$ 5200$, but strangely there was a sadden significant drop in prices of Brent from $\$ 5200$ range to reach the range of $\$ 1300$ in the following years and stayed below $\$ 2000$ up to the year of 2009. Within the same period, the prices of Gold were also between $\$ 2000$ and $\$ 3000$ ranges. In the year of 2010 , there was further fluctuation in the prices of the two commodities. But that of Gold this time around was above $\$ 3000$ whereas, prices of Brent remained relatively below $\$ 3000$. Thus, in the year of 2012, there was another significant jump in prices of these two commodities. For the first time, prices of the two commodities went above $\$ 4000$ with Gold experiencing higher increment. Around the year of 2015, prices of Brent started experiencing sharp decline and it continued up to 2016, when prices hit a minimal of $\$ 1000$. Although price of Gold equally experienced marginal decline in price but remained above $\$ 3000$. Thereafter, the two commodities in the year of 2017, all started experiencing rise in prices.

To sum up, one could say based on the dynamic graphs above, that prices of Brent are relatively volatile as compared to prices of Gold. Because, whenever there was a sadden price increment within the same period, the price of Brent experienced a significant drop. For instance, in the years of 2007 and 2008 which was the global financial crises period, it is clear on the graphs how much the price of Brent dramatically dropped compared to the Gold one. 


\section{Empirical Results}

\section{Wavelet Coherence: GOLD vs BRENT}

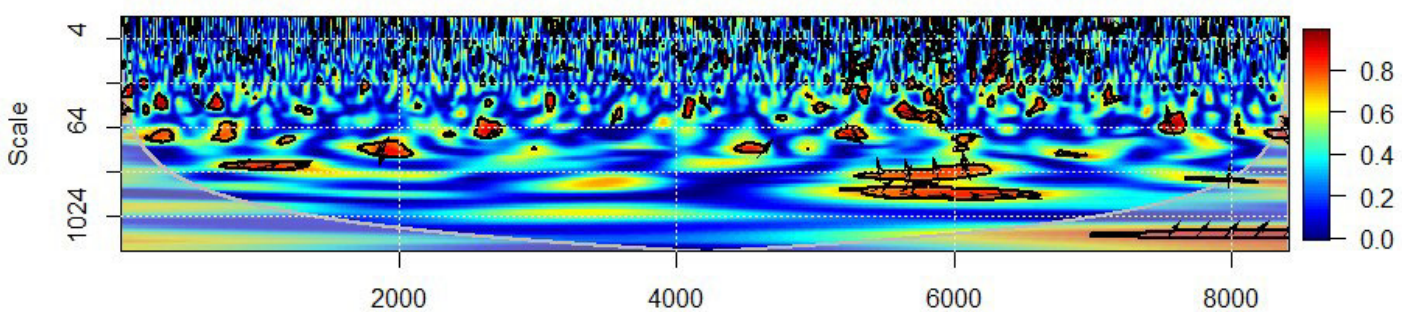

The wavelet coherence test shows that in the medium run, the Gold in certain period is hedge for the Brent as in that period both two variables move in the same direction, which means that there is no causality between the two variables, rather both are influenced by a third side. Furthermore, since there is no cause and effect between the two variables, they are then moving parallelly in the same direction. The causality is when one variable is the result of occurrence of the other variable, therefore the one that causes the occurrence is the leader for the second one(Statistics, n.d.). Moving on in the same run, both two variables, Gold and Brent move in different directions up and down but there is no sign moving right or left to show any correlation between Gold and Brent, most of the times the sign is either going up or down.

\section{Conclusion}

In conclusion, the non-intermediation income contributes positively in the bank efficiency. This was indicated by the positive correlation between the bank efficiency and the non-intermediation income, which means that the government spending increases whenever there is a high level of non-intermediation income.

In addition, the co-movement graphs show that the Crude Oil Price (Brent) is mostly fluctuated. Its price quickly changes every time while the Gold price is almost stable all the time, it slightly fluctuates sometimes. Therefore, many investors intend to invest in Gold rather than in the Crude Oil in London Bullion.

\section{References}

Baur, D. G., \& McDermott, T. K. (2010). Is gold a safe haven? International evidence. Journal of Banking and Finance, 34(8), 1886-1898. https://doi.org/10.1016/j.jbankfin.2009.12.008

Crude Oil Prices: Brent - Europe. (2018). Retrieved from https://fred.stlouisfed.org/series/DCOILBRENTEU

DAMANKAH, B. S., TSEDE, O. A.-, \& AMANKWAA, A. (2014). Analysis of Non-Interest Income of Commercial Banks in Ghana. International Journal of Academic Research in Accounting, Finance and Management Sciences, 4(4). https://doi.org/10.6007/IJARAFMS/v4-i4/1343

EryiĞit, M. (2017). Short-term and long-term relationships between gold prices and precious metal (Palladium, silver and platinum) and energy (crude oil and gasoline) prices. Economic Research-Ekonomska Istrazivanja, 30(1), 499-510. https://doi.org/10.1080/1331677X.2017.1305778

LBMA. (2016). A guide to The London Bullion Market Association The London Bullion Market Association, 44(0).

López-Espinosa, G., Moreno, A., \& Pérez de Gracia, F. (2011). Banks' net interest margin in the 2000s: A macro-accounting international perspective. Journal of International Money and Finance, 30(6), 12141233. https://doi.org/10.1016/j.jimonfin.2011.06.001

Malatesta, Fabrizio, S. M. and A. Z. (n.d.). THE SHADOW BANKING SYSTEM IN THE EURO AREA: KEY FEATURES AND THE FUNDING OF FIRMS Fabrizio Malatesta *, Sergio Masciantonio $\S$ and Andrea Zaghini $\$$.

Malim, N. A. K., \& Masron, T. A. (2018). What Drives Bank Margins During and Post-Crisis? a Comparison Between Islamic and Conventional Banks. Asian Academy of Management Journal of Accounting \& Finance, 14(1), 107-126. https://doi.org/10.21315/aamjaf2018.14.1.5

Statistics, $\mathrm{c}=\mathrm{AU} ; \mathrm{o}=$ Commonwealth of A. ou=Australian B. of. (n.d.). Statistical Language - Correlation and Causation. Retrieved from http://www.abs.gov.au/websitedbs/a3121120.nsf/home/statistical+language++ correlation+and+causation 